and contemporary of his in the actuarial world has written that it could truly be said of Trouncer, in words akin to those used by Dr Johnson when writing of Oliver Goldsmith, that 'he left few things untouched and touched nothing that he did not adorn'. With that summing up of 'Trouncer's journey through life no one who knew him intimately is likely to disagree.

A. W. E.

\title{
VICTOR ROY SMITH
}

A VERY prominent Canadian Actuary, V. R. Smith, M.A., A.I.A., A.A.S., F.A.I.A., President of the American Institute of Actuaries, 193738 , died suddenly on 2 I November 1947, while on a visit to London, England.

V. R. Smith was born in Cobourg, Ontario, on 23 November 1883 . Upon his graduation from Trinity College, University of 'Toronto, in 1905 , he engaged in chartered accountancy for a period of three years and then joined the actuarial department of the Confederation Life Association. He remained in the service of the same company throughout the remainder of his life. His boundless energy and ability resulted in steady advancement. He was appointed Assistant Actuary in 1914, Actuary in 1917, Assistant General Manager and Actuary in 1929, General Manager and Actuary in 1932 , and President in 1944.

He became an Associate of the Actuarial Society of America in $191 \mathrm{I}$ and an Associate of the Institute of Actuaries in 1913. In 1917 he was elected President of the Actuaries' Club (now the Canadian Association of Actuaries). In 1925 he was elected a Fellow of the American Institute of Actuaries and in 1937 was elected President of that Institute. He presented papers on actuarial subjects to both the Actuarial Society of America and the American Institute of Actuaries. He also presented papers to many other organizations, including the International Congresses of Actuaries in Rome and Paris.

His interest and activities extended far beyond the actuarial field. He served with distinction as President of the Canadian Life Insurance Officers Association in 5936 and President of the Insurance Institute of Canada in 1942 . He was President of the Canadian Club of Toronto in 1938. From I940 to 1946 he was a member of the Advisory Committee established under Canada's Unemployment Insurance Act. At the time of his death he was a member of the executive committee of the Canadian Chamber of Commerce. He was chairman of the corporation executive of 'Trinity College, University of 'Toronto, and a director of Wellesley Hospital in Toronto, and he also served on a number of company directorates.

$V$. R. Smith was well known to many members of the Institute. He was a frequent visitor to Great Britain in connexion with the business of his own company. As President of the American Institute of Actuaries in 1938 he played a prominent part in welcoming the members of the Institute of Actuaries and the Faculty of Actuaries who visited North America in that year. It was his privilege to propose the toast to the visitors at the banquet held in their honour in New York by the Actuarial Society and the American Institute of Actuaries. He prepared a paper on The development of the investment pavers of Canadian life insurance companies orer the last one humited years for the Centenary Assembly of the Institute but unfortunately he did not live to present it in person.

It is obvious from even this brief review that he possessed tremendous energy and very high ability. He had a strong sense of responsibility and gave un- 
sparingly of his time and talents to all those endeavours to which he set his hand. His name was never associated with an organization which did not receive benefit from his aggressive interest and mature judgment. It was characteristic of him that despite the warnings of his physician and the urgings of his associates to lessen his activities, he carried through his visit to England in November 1947 because of his conviction that the matter of business which prompted the visit was of national importance to Canada. While he set a high standard of effort for himself, he was always most considerate and solicitous of the welfare of his associates.

He will be greatly missed by a host of friends in Canada, the United States and the British Isles.

J. G. B.

\section{ERNEST FRANK SPURGEON}

THE passing, on 20 August 1948, of Ernest Frank Spurgeon, at the age of 67 , deprived the Institute of one who had rendered long and devoted service to his profession and to his Company, the Prudential. He entered the service of that company as a junior clerk at Head Office on leaving school, and rose to the position of a Director which he held at the time of his death.

Spurgeon became a Fellow in 1906 . He served on the Council $1923^{-26}$ and ro28-34. He was Honorary Secretary 1929-31, and Vice-President 1931-33. He served as a tutor $1911_{-15}$ and $1919-20$, and he was an examiner 1920-27. His outstanding service to the profession was the revision of King's Text-book, the Institute of Actuaries' Text-book, Part II, a task entrusted to him by the Council and one which he completed in I922. King's Text-book had been in use for over thirty-five years, and is still remembered by the survivors of an older generation with gratitude and, indeed, with some affection for its remarkable lucidity. The devclopments which had taken place in actuarial science during that long period were such that more than a mere revision was necessary. In his review of Spurgeon's Text-bonk ( F.I.A. Vol. Liv, p. 104), Levine pays a tribute to Spurgeon for the 'very great success' with which he surmounted the difficulties of the task he undertook, adding that 'both he and the Institute are to be warmly congratulated on the result of his work'.

Spurgeon had been a tutor for some years, and in the rewriting of the textbook he had ever in his mind the needs of the student. As Levine said, 'his book is obviously the work of a very able and successful tutor'. Sir Alfred Watson, in the introduction to the new book, said that Spurgeon 'brought to his task the indispensable qualifications of long experience as a tutor and a conspicuous gift of exposition'.

Spurgeon's career with the Prudential was a varied one. On the introduction of National Health Insurance in 1912 he was transferred to that side of his Company's activities. He became 'Treasurer of the Prudential Approved Societies in $19 I_{4}$, and threw himself with zeal into that new field of activity where he did so much good work. He served on the Consultative Council of the Ministry of Health $1923^{-29}$. In 1925 , he returned to the life assurance side of the business and became Deputy General Manager under Sir Joseph Burn. He did not, however, forsake the field of National Health Insurance, for he simultaneously became a member of the Committee of Management of the Prudential Approved Societies, subsequently becoming Chairman. That position he held 